\title{
PELATIHAN PEMBUATAN SABUN DENGAN BAHAN LIMBAH PROPOLIS KELLE DI DESA AAN KLUNGKUNG
}

\author{
K.W. Astuti ${ }^{1}$, N.P.A.D. Wijayanti ${ }^{2}$, L.P.I. Harini ${ }^{3}$, I G.S. Astawa ${ }^{4}$
}

\begin{abstract}
ABSTRAK
Kelompok peternak lebah madu Trigona spp di Desa Aan, Kecamatan Banjarangkan, Kabupaten Klungkung melakukan budidaya lebah madu Trigona spp untuk mendapatkan madu kelle yang terkontrol kualitasnya. Dalam proses pengolahan madu kelle ini dihasilkan propolis yang sampai saat ini belum dapat dimanfaatkan oleh kelompok peternak. Permasalahan yang ada adalah kurangnya pengetahuan untuk mengolah limbah propolis ini menjadi produk yang memiliki nilai jual tinggi.Program pelatihan yang diberikan adalah pelatihan mengolah propolis menjadi produk bernilai jual yakni sabun padat dengan kandungan aktif propolis. Dalam program ini akan dibentuk Focus Group Disscussion (FGD) yang terdiri dari 5 orang setiap 1 FGD. Program ini diawali dengan pemberian informasi mengenai pengolahan propolis menjadi produk baru kemudian dilanjutkan dengan diskusi dan tanya jawab. Untuk memaksimalkan penyampaian materi tersebut diatas maka tim memberikan modul. Setelah penyampaian informasi dilanjutkan dengan pelatihan dan praktek langsung untuk mengaplikasikan ilmu yang telah diterima. Setelah pelaksanaan workshop kelompok peternak lebah madu Trigona spp di Desa Aan, Kecamatan Banjarangkan, Kabupaten Klungkung sudah berhasil membuat sabun padat dengan bahan aktif propolis.
\end{abstract}

Kata kunci : propolis, sabun padat, pelatihan, Trigona, madu kelle

\begin{abstract}
Trigona honey bee breeder group in Aan Village, Banjarangkan District, Klungkung Regency conducted Trigona honey bee cultivation to get high quality kelle honey. In the process of harvesting kelle honey, propolis is produced, which until now has not been utilized by farmers. The problem is lack of knowledge to process this propolis waste into a product that has a high selling value. In this workshop, Trigona honey bee breeder are taught to process propolis into solid soap with propolis as active ingredients. Training was formed in Focus Group Disscussion (FGD) consisting of 5 people every 1 FGD. Training begins with the presentation on how to make solid soap of propolis and followed by discussion. In session 2, training was continued by hands-on practice to apply the knowledge that has been received. After the workshop of the Trigona honey bee breeder group in Aan Village, Banjarangkan Subdistrict, Klungkung District had succeeded in making solid soap with propolis as active ingredients.
\end{abstract}

Keywords: propolis, solid soap, workshop, Trigona, kelle honey

\section{PENDAhuluan}

Kelompok peternak lebah madu Trigona spp di Desa Aan, Kecamatan Banjarangkan, Kabupaten Klungkung melakukan budidaya lebah madu Trigona spp untuk mendapatkan madu kelle yang terkontrol kualitasnya. Dalam proses pengolahan madu kelle ini dihasilkan propolis yang sampai

\footnotetext{
${ }^{1}$ Dosen Program Studi Farmasi Fakultas MIPA Universitas Udayana, ketutwidyani@ gmail.com

${ }^{2}$ Dosen Program Studi Farmasi Fakultas MIPA Universitas Udayana, dwijayanti@gmail.com

${ }^{3}$ Program Studi Matematika Fakultas MIPA Universitas Udayana, ballidah@gmail.com

${ }^{4}$ Program Studi Teknik Informatika Fakultas MIPA Universitas Udayana, santiastawa@gmail.com
} 
saat ini belum dapat dimanfaatkan oleh kelompok peternak. Hingga saat ini propolis yang diperoleh dari pengolahan madu ini hanya menjadi limbah. Permasalahan yang ada adalah kurangnya pengetahuan untuk mengolah limbah propolis ini menjadi produk yang memiliki nilai jual tinggi. Salah satunya adalah pengembangan usaha mengolah propolis menjadi produk yang dapat bermanfaat bagi kesehatan.

Dari analisis situasi ini maka perlu dilakukan suatu pelatihan untuk kelompok peternak lebah madu Trigona spp. dalam pengolahan propolis menjadi suatu produk yang memiliki nilai jual yang lebih tinggi namun dengan pemanfaatan sarana prasarana serta bahan dasar yang memadai. Produk spa menjadi salah satu sasaran produk yang akan dikembangkan dan dapat dijual sebagain produk oleholeh khas Bali. Selain itu saat ini perkembangan usaha spa terutama di Bali semakin berkembang pesat seiring dengan semakin banyaknya tempat wisata yang dieksplorasi sehingga para wisatawan semakin tertarik untuk berlibur dan menikmati keindahan panorama serta suasana yang disajikan. Spa sebagai salah satu sarana dan fasilitas yang ditawarkan, menjadi ketertarikan wisatawan untuk pergi ke pulau dewata. Hal ini membuat banyak pengusaha berlomba-lomba untuk mendirikan spa serta bersaing untuk tidak hanya menonjolkan jasa saja tetapi juga produk andalan dari spa tersebut. Banyak produk spa saat ini menonjolkan kalimat "Back to Nature" dan fenomena ini dapat dimanfaatkan oleh penduduk lokal untuk dapat mengekplorasi keanekaragaman hayati yang dimiliki menjadi bahan baku atau bahkan dapat memasok produk spa tersebut (Perkosmi, 2012). Salah satu bahan yang akan dijadikan sebagai bahan baku utama produk spa yaitu propolis.

Pada program ini akan diberikan "Pelatihan Pembuatan Produk Kosmetik Spa Berbahan Dasar Propolis", yaitu sabun padat dengan kandungan aktif propolis. Harapannya dengan dilakukannya program ini, maka Kelompok peternak lebah madu Trigona spp di Desa Aan, Kecamatan Banjarangkan, Kabupaten Klungkung dapat mengolah sendiri propolis tersebut menjadi suatu produk dengan nilai jual yang lebih tinggi serta dapat menjadi pemasok untuk usaha spa khususnya sabun padat.

\section{METODE PEMECAHAN MASALAH}

Melihat permasalahan yang dialami oleh mitra usaha yaitu cara mengolah limbah propolis yang dihasilkan dari pengolah madu kelle di Desa Aan, Kecamatan Banjarangkan, Kabupaten Klungkung maka akan dilakukan program Pelatihan Pembuatan Produk Kosmetik Spa Berbahan Dasar Propolis dimana program ini berupa pemberian materi dan pelatihan guna mengatasi permasalahan kelompok peternak lebah madu. Sistem yang akan dilakukan dalam workshop ini adalah pembagian peternak lebah madu sebagai mitra. Dalam program ini akan dibentuk Focus Group Disscussion (FGD) yang terdiri dari 5 orang setiap 1 FGD.

Program ini diawali dengan pemberian informasi mengenai pengolahan propolis menjadi produk baru baru yakni sabun padat serta teori tentang pembuatan sabun dalam skala industri rumah tangga kemudian dilanjutkan dengan diskusi dan tanya jawab. Selain itu tiap peserta akan diberikan modul materi untuk memudahkan pelatihan. Setelah penyampaian materi dilanjutkan dengan pelatihan dan praktek langsung pembuatan sabun padat. Sabun merupakan salah satu bentuk sediaan kosmetika pembersih dan perawatan. Menurut peraturan Kepala BPOM RI Nomor 18 Tahun 2015 tentang persyaratan teknis bahan kosmetika. Kosmetika haruslah memenuhi 3 syarat yaitu bermutu, aman dan memiliki manfaat. Sehingga dalam pelaksanaan kemitraan ini akan sangat diperhatikan ketiga syarat tersebut sehingga harapan daya belinya menjadi tinggi dan mampu meningkatkan taraf perekonomian dari mitra usaha. Adapun metode yang dapat dilakukan adalah :

\subsection{Formulasi Sabun Propolis}

Sabun propolis yang akan dibuat memiliki komposisi : 500 gram minyak kelapa, 50 gram NaOH, 5 gram propolis cair, 5 gram aroma madu, dan 150 gram aquadest.

\subsection{Prosedur Pembuatan Sabun}


Sabun dibuat dengan cara menakar aquadest sebanyak $150 \mathrm{ml}$. NaOH ditimbang sebanyak $50 \mathrm{gr}$ lalu dimasukkan ke dalam air sedikit demi sedikit. Campuran diaduk hingga rata. Larutan ditunggu hingga dingin. Minyak kelapa, propolis dan fragrance madu ditimbang. Bahan minyak dimasukkan ke dalam blender lalu ditambahkan larutan $\mathrm{NaOH}$ secara perlahan. Campuran diblender hingga fase trace (campuran mulai mengental dan meninggalkan jejak jika ditekan dengan sendok). Propolis dan fragrance ditambahkan lalu dilanjutkan pengadukan hingga rata. Campuran dituangkan ke dalam cetakan. Setelah sabun menjadi padat, sabun dikeluarkan dari cetakan. Sabun didiamkan selama 2-4 minggu sebelum bisa digunakan (Tranggono, 2007).

\subsection{Pengemasan Produk Sabun Padat Propolis}

Produk sabun padat propolis akan dikemas secara menarik menggunakan kombinasi bahan ramah lingkungan seperti kertas daur ulang, pelepah daun pisang, daun bambu.

\subsection{Pemasaran Produk Sabun Padat Propolis}

Produk sabun padat propolis sangat potensial dipasarkan di wilayah bali pada umumnya. Pemasarannya dapat melibatkan kelompok masyarakat mitra usaha dengan cara mengikuti sejumlah pameran, dijual sebagai souvenir khas Klungkung yang ditawarkan pada wisatawan domestik dan mancanegara, serta dapat dijual kepada industri spa dalam bentuk kerjasama pemasaran produk

\section{HASIL DAN PEMBAHASAN}

Kegiatan pelatihan dan praktek langsung pembuatan sabun disambut dengan sangat antusias dibuktikan dengan kehadiran peserta sebesar $100 \%$ saat dilakukan pelatihan. Pelatihan tahap 1 berhasil merangsang keingintahuan kelompok ternak lebah untuk menanyakan segala hal yang belum mereka pahami. Pada tahap ini teori dasar mengenai pembuatan sabun disampaikan melalui metode presentasi.

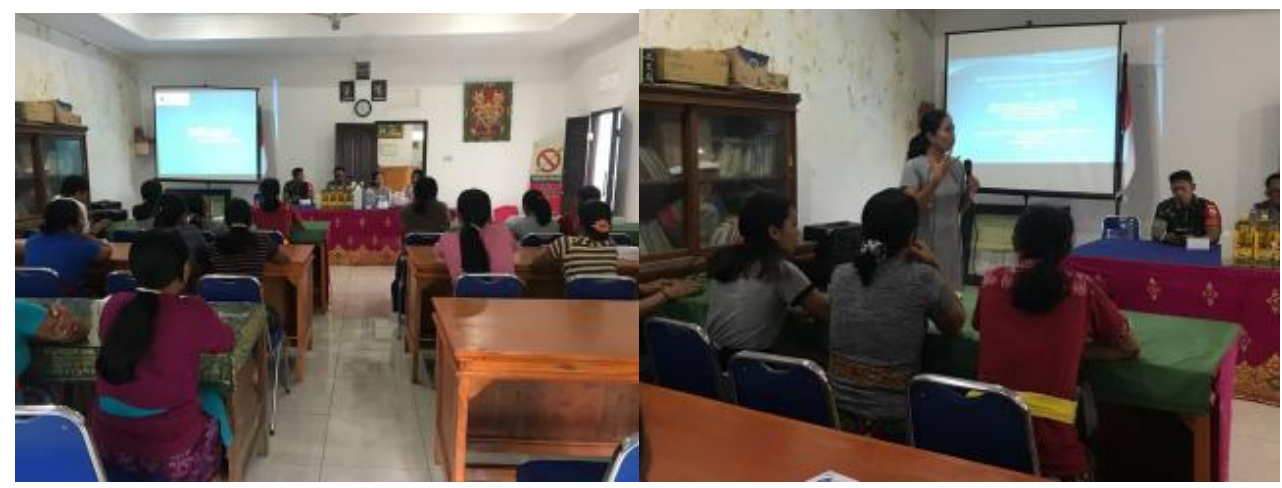

Gambar 3.1. Pemberian materi dengan metode presentasi

Praktek pembuatan sabun terbagi menjadi 2 sesi. Sesi pertama dilakukan dengan cara demo pembuatan sabun yang dilakukan oleh pemberi materi. Pada sesi 2, masing-masing FGD diberikan kesempatan langsung untuk mempraktekkan pembuatan sabun. Hal ini membuat peserta lebih bersemangat karena dapat mengerjakan pembuatan sabun secara mandiri.

Pada gambar 3.2 dan 3.3 menunjukkan proses pelatihan yang dilakukan di Desa Aan Klungkung Kecamatan Banjarangkan Klungkung 


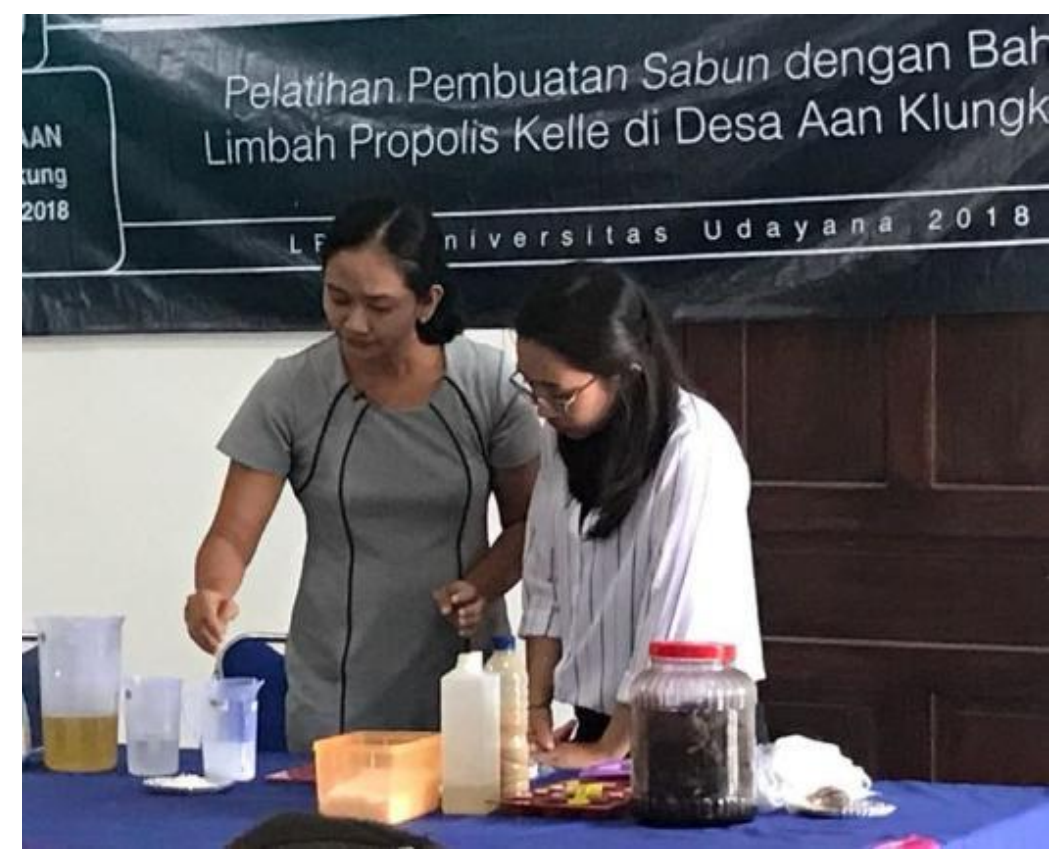

Gambar 3.2. Demo Pembuatan Sabun

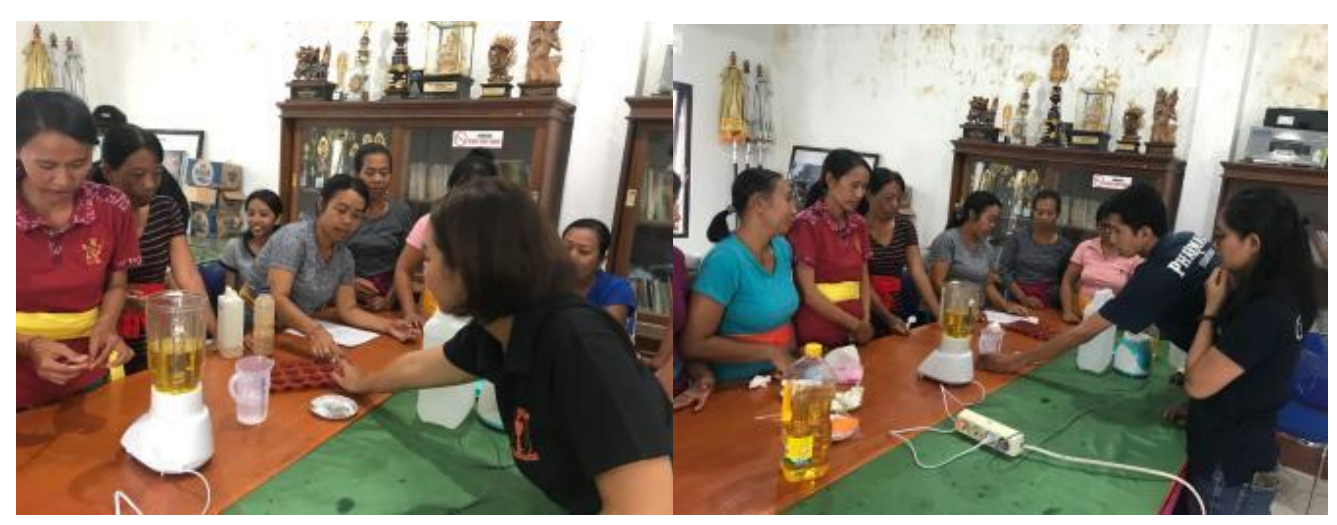

Gambar 3.3. Pelatihan dan Praktek Langsung Pembuatan Sabun Padat

Evaluasi kegiatan pelatihan ini dilakukan oleh tim pendamping dengan menilai produk sabun yang dihasilkan oleh masing-masing FGD. FGD yang menghasilkan produk yang paling baik dan sesuai kriteria (aroma, bentuk, tekstur dan warna produk) mendapatkan hadiah. Hal inilah yang menyebabkan masing-masing FGD bersemangat untuk menghasilkan produk yang terbaik. Selain itu hal yang dapat dijadikan sebagai parameter bahwa kegiatan pelatihan telah berlangsung dengan sukses adalah masyarakat yang antusias mengerjakan dan mengolah hasil alam menjadi produk yang berguna. 


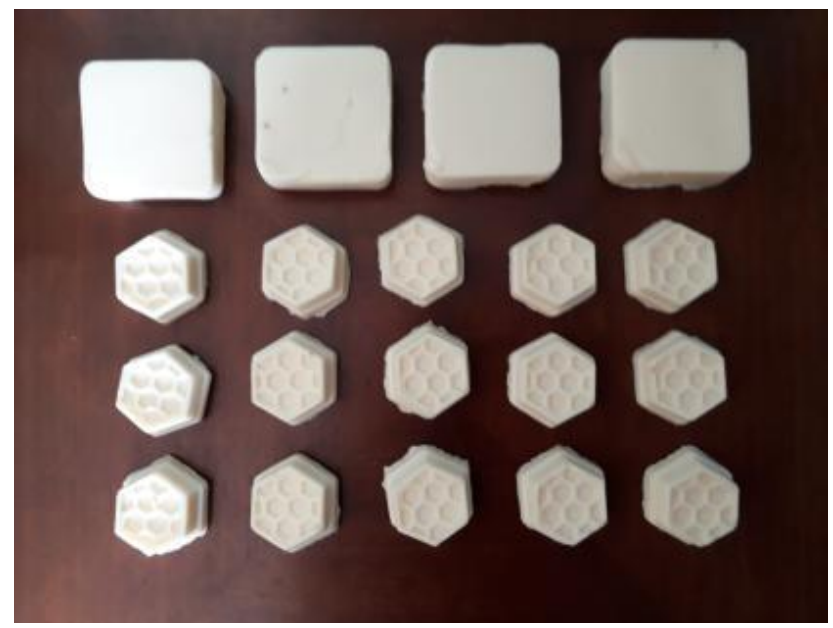

Gambar 3.4. Sabun Propolis Yang Dihasilkan

Pada akhir kegiatan para peserta FGD berhak atas produk sabun yang telah diproduksi beserta alat dan bahan yang diberikan oleh tim pelaksana pengabdian masyarakat. Penyerahan alat dan bahan ini bertujuan agar para peserta dapat terus berlatih dan mengembangkan produk sabun propolis ini secara berkelanjutan.

\section{SIMPULAN DAN SARAN}

\subsection{Simpulan}

Kelompok peternak lebah madu Trigona spp di Desa Aan, Kecamatan Banjarangkan, Kabupaten Klungkung telah mampu melakukan pengolahan limbah propolis menjadi produk sabun propolis.

\subsection{Saran}

Perlu dilakukan diversifikasi produk lain dari limbah propolis seperti lulur atau produk spa lainnya.

\section{UCAPAN TERIMA KASIH}

Penulis ingin mengucapkan terima kasih kepada Lembaga Penelitian dan Pengabdian Masyarakat Universitas Udayana atas dukungan yang telah diberikan dalam pelaksanaan pelatihan ini.

\section{DAFTAR PUSTAKA}

BPOM RI. 2015. Peraturan Kepala Badan Pengawas Obat Dan Makanan Republik Indonesia Nomor 18 Tahun 2015 Tentang Persyaratan Teknis Bahan Kosmetika.

$\begin{array}{llllll}\text { Perkosmi. } & 2012 . & \text { Pasar } & \text { Kosmetik } & \text { Indonesia } & \text { Available }\end{array}$ http://www.indonesiafinancetoday.com/read/16014/PasarKosmetikIndonesia-2012

Tranggono, I. R dan F. Latifah. 2007. Buku Pegangan Ilmu Pengetahuan Kosmetik. Jakarta: PT Gramedia Pustaka Utama. Halaman: 5-25. 